\section{Identification of barbiturates by thin-layer chromatography}

\author{
W. H. C. WALKER ${ }^{1}$ and J. K. WOOD From the Bio- \\ chemistry Department, Manchester Royal \\ Infirmary
}

Barbiturates can be separated rapidly and easily by thin-layer chromatography (Sunshine, 1963). Slow, intermediate, and fast acting barbiturates have respectively low, intermediate, and high $R_{\mathfrak{f}}$ values. The intermediate group contains many of the drugs encountered in cases of overdose and identification of the actual barbiturate concerned may be impossible because of the closely similar $\mathbf{R}_{\mathbf{f}}$ values of this group.

Jackson (1960) described treatment with hot sulphuric acid before paper chromatography to distinguish between barbiturates of similar chromatographic mobility. The inert nature of the silica gel supporting medium used in thin-layer separations enables this acid treatment to be carried out directly on the plate with consequent convenience and saving of time.

\section{METHOD}

Chromatography is carried out by the method of Sunshine (1963), using $10 \times 20 \mathrm{~cm}$. glass plates $(24 \mathrm{oz}$. glass) coated with a $250 \mu$ layer of silica gel G (Merck). The developing solvent is chloroform-acetone $(9: 1)$. The tank should be the smallest that will accommodate the plate since failure to saturate the vapour phase results in high $R_{\mathfrak{f}}$ values and poor separation.

STANDARD SOLUTIONS Stock $1 \%$ standard solutions are prepared in chloroform and keep at least three months at $5^{\circ} \mathrm{C}$. A composite standard containing phenobarbitone, butobarbitone, pentobarbitone, quinalbarbitone, and hexobarbitone each at a concentration of $0.1 \%$ is prepared by pooling 1 volume of each of the stock standards, evaporating to dryness and dissolving the residue in 10 volumes of $80 \%$ ethanol.

'Present address: Department of Pathology, Bristol Royal Infirmary. Received for publication 29 December 1964.

Simplified technique for counting the number of bacteria in urine and other fluids-concluded

McGeachie, J., and Kennedy, A. C. (1963). J. clin. Path., 16, 32. Marple, C. D. (1941). Ann. intern. Med., 14, 2220.

Martin, C. M., and Bookrajian, E. N. (1962). Arch. intern. Med., 110, 703.

Monzon, O. T., Ory, E. M., Dobson, H. L., Carter, E., and Yow, E. M. (1958). New Engl. J. Med., 259, 764

Mou, T. W., and Feldman, H. A. (1961). Amer. J. clin. Path., 35, 572 O'Sullivan, D. T., Fitzgerald, M. G., Meynell, M. J., and Malins, J. M. (1960). J. clin. Path., 13, 527.

Sanford, J. P., Favour, C. B., Mao, F. H., and Harrison, J. H. (1956). Amer. J. Med., 20, 88.

Turner, G. C. (1961). Lancet, 2, 1062.
TEST SAMPLE The concentration of barbiturate in th biological fluid is determined by the method of Broughton (1956). The two alkaline extracts are the pooled, acidified with $\mathbf{N}$ hydrochloric acid, and the barbiturate extracted into about $5 \mathrm{ml}$. chloroform. The aqueous layer is removed and the chloroform filtereq into a dry evaporating dish. The chloroform is evaporate under a current of warm air and the residue dissolved i⿱ $0.2 \mathrm{ml} .80 \%$ ethanol. If $\mathrm{x} \mathrm{ml}$. of the original fluig containing y mg. barbiturate $/ 100 \mathrm{ml}$. was taken for the quantitative estimation, then $\frac{100}{\mathrm{xy}} \mu \mathrm{l}$. of the ethanolie solution will contain theoretically $5 \mu \mathrm{g}$. barbiturate There are small losses in the extraction procedure bư⿱ this volume contains sufficient barbiturate to reveal minor components and not enough to overload the chromatopo gram. Two ' $5 \mu \mathrm{g}$.' samples are applied to the plate as small spots $3 \mathrm{~cm}$. apart and $2 \mathrm{~cm}$. from the bottom edgê of the plate. Alternating with these are placed three $2 \mu \hat{\Gamma}_{\dot{H}}$ spots of the composite standard containing $2 \mu \mathrm{g}$. of eact of the standards.

ACID TREATMENT The plate is placed in a hot air oven at $135^{\circ} \mathrm{C}$. for $10 \mathrm{~min}$., removed while a spot of concentrated sulphuric acid is dropped over one of the two sample spots, and replaced in the oven for a furtheo five minutes. These times are not critical; the reactio goes to completion within one minute at $135^{\circ} \mathrm{C}$. althoug application of acid to the cold plate with subsequen heating produces incomplete and variable reactions eves after one hour at $150^{\circ} \mathrm{C}$. The plate is removed from the oven for application of acid so that the amount delivere from a fine glass capillary can be carefully regulated to be only just sufficient to cover the sample spot. Excessof acid leads to local deformation of the solvent frons and retardation of the solute.

DEVELOPMENT At the end of the five-minute period the plate is removed from the oven, allowed to cool for five minutes and placed in the developing tank. Aftee 90 minutes the solvent front has risen about $15 \mathrm{~cm}$. and the plate is removed and dried under a current of warms air.

DETECTION The Shandon Laboratory spray gun is very suitable for spraying reagents. The metal nozzle soon disintegrates due to amalgam formation and is bes 0 replaced by a length of capillary bore glass tubing whose upper end is ground to a conical profile.

The plate is sprayed first with mercuric sulphate solution $(5 \%$ mercuric sulphate in $20 \% \mathrm{v} / \mathrm{v}$ sulphurice acid; 1 part diluted with 1 part water just before use which shows some barbiturates as white spots against a grey background. Further spraying with diphenyl carbazone solution (freshly prepared $10 \mathrm{mg} . / 100 \mathrm{ml} \frac{\mathrm{T}}{\mathrm{T}}$ acetone) results in a uniform violet background which rapidly fades to reveal barbiturates as blue or viole spots. Some non-barbiturates in biological extracts giveo violet spots which are well away from the standards and soon fade. 
The composite standard resolves into four spots: the slowest is phenobarbitone, then a violet oval spot composed of butobarbitone and the slightly faster pentobarbitone, then a blue round spot of quinalbarbitone, and finally the fast hexobarbitone. Of the 10 commonly used barbiturates listed in the Table, three migrate at the rate of butobarbitone and three at the rate of pentobarbitone but in both groups a specific identification can be made by the appearance after acid treatment. Cyclobarbitone and heptabarbitone give distinctive slow blue spots after acid treatment, while pentobarbitone, quinalbarbitone, and hexobarbitone only just clear the halo of acid and appear as crescents at its upper margin.

The yellow colour produced by spraying allobarbitone, cyclobarbitone, heptabarbitone, quinalbarbitone, and hexobarbitone with $0 \cdot 1 \%$ aqueous potassium permanganate may be useful for confirmation but helps little with primary identification except perhaps when a mixture of barbiturates is present.

\begin{tabular}{|c|c|c|c|c|}
\hline Official Name & Synonym & $R_{f}$ Ratio $^{1}$ & $\begin{array}{c}R_{f} \text { Ratio }^{1} \\
\text { after Acid }\end{array}$ & $\begin{array}{l}\text { Colour } \\
\text { Reaction }\end{array}$ \\
\hline Barbitone & Veronal & 1.0 & $1 \cdot 0$ & $\mathbf{W} \mathbf{V}$ \\
\hline Phenobarbitone & Luminal & $1 \cdot 0$ & $1 \cdot 0$ & $\mathbf{W} \mathbf{V}$ \\
\hline Butobarbitone & Soneryl & $1 \cdot 3$ & $1 \cdot 3$ & $\mathbf{w} \mathbf{V}$ \\
\hline Allobarbitone & Dial & $1 \cdot 3$ & $\begin{array}{l}\text { Destroyed } \\
\text { by acid } \\
\text { treatment }\end{array}$ & $-\mathbf{B}$ \\
\hline Cyclobarbitone & Phanodorm & $1 \cdot 3$ & $0 \cdot 2$ & $-\mathbf{V}$ \\
\hline Pentobarbitone & Nembutal & $1 \cdot 4$ & $0 \cdot 1$ & W V \\
\hline Amylobarbitone & Amytal & 1.4 & $1 \cdot 4$ & $\mathbf{W} \mathbf{V}$ \\
\hline Heptabarbitone & Medomin & 1.4 & 0.2 & $\mathbf{W} \mathbf{V}$ \\
\hline Quinalbarbitone & Seconal & 1.6 & $0 \cdot 1$ & W B \\
\hline Hexobarbitone & Evipan & 1.9 & $0 \cdot 1$ & $-\mathrm{V}$ \\
\hline \multicolumn{5}{|c|}{$\begin{array}{l}{ }^{1} \mathbf{R} \text { atio of } \mathbf{R}_{\mathbf{f}} \text { of substituted barbiturate to that of barbitone } \\
\mathbf{W}=\text { White after mercuric sulphate spray } \\
\mathbf{V}=\text { Violet after diphenylcarbazone spray } \\
\mathbf{B}=\text { Blue after diphenylcarbazone spray }\end{array}$} \\
\hline
\end{tabular}

We would like to thank Mr. H. Varley for his encouragement.

\section{REFERENCES}

Broughton, P. M. G. (1956). Biochem. J., 63, 207.

Jackson, J. V. (1960). In Chromatographic and Electropheretic Techniques, edited by I. Smith, vol. 1, pp. 387-388. Heinemann, London.

Sunshine, I. (1963). Amer. J. clin. Path., 40, 576.

\section{Book reviews}

FLUORESCENCE MICROSCOPY IN THE CYTODIAGNOSIS OF Cancer By G. Sani, U. Citti, G. Caramazza and P. Quinto. (Pp. xvi + 195; illustrated. \$27.50.) Springfield, Illinois: Charles C. Thomas. 1964.

This beautiful atlas of colour photographs shows the appearances in sections and in smears of normal and pathological cervical epithelium and endometrium, as seen with acridine orange fluorescence. This method has certain concrete advantages; it is rapid both in preparation and in examination of slides, and the results give such pleasure that the tedium of cytodiagnosis is reduced. But the wonderful colours are ephemeral, and this makes it unacceptable to many. Besides the gynaecological applications, further pictures are given of cells from other pathological sources, but these are treated only very briefly and might mislead. Chapters on the physical and chemical bases of fluorescence are given, as well as illustrated descriptions of the principal fluorescence microscopy sets on the market (but without fool-proof descriptions of how to use them). There is an extensive bibliography with titles.

ARTHUR SPRIGGS

EXFOLIATIVE CYTOLOGY IN GYNAECOLOGICAL PRACTICE

By Erica G. Wachtel. (Pp. xiii + 203; 188 figures. 45s.)

London: Butterworth \& Co. (Publishers) Ltd. 1964. Dr. E. G. Wachtel writes with the authority of experience and draws a stimulating balance between the usefulness and limitations of cytological diagnosis.

There are numerous illustrative photomicrographs of excellent quality, and the book is an important yet a very readable British publication on the subject.

K. K. HUSSAIN

CLASSIFICATION OF BRAIN TUMOURS Edited by K. J. Zulch and A. L. Woolf. (Pp. X + 217; illustrated. 118s.) Vienna: Springer-Verlag. 1964.

This volume reports the papers and discussions which were heard at an international symposium in the summer of 1961 . It is surprising that it has required almost three years to produce the report for there is little evidence of editing, either in the papers or the subsequent comments. One is forced to question if the verbatim reporting of discussions in this way is really worth while: the phrase 'thank you very much', for instance, appears on almost every discussion page, sometimes three or four times!

The symposium has as its objects to improve the classification of cerebral tumours and to clarify controversial problems. While it may have attained these objectives for the small group of participants, little clarification comes across to the reader.

Although workers particularly interested in cerebral tumours in their pathological, veterinary, and experi- 